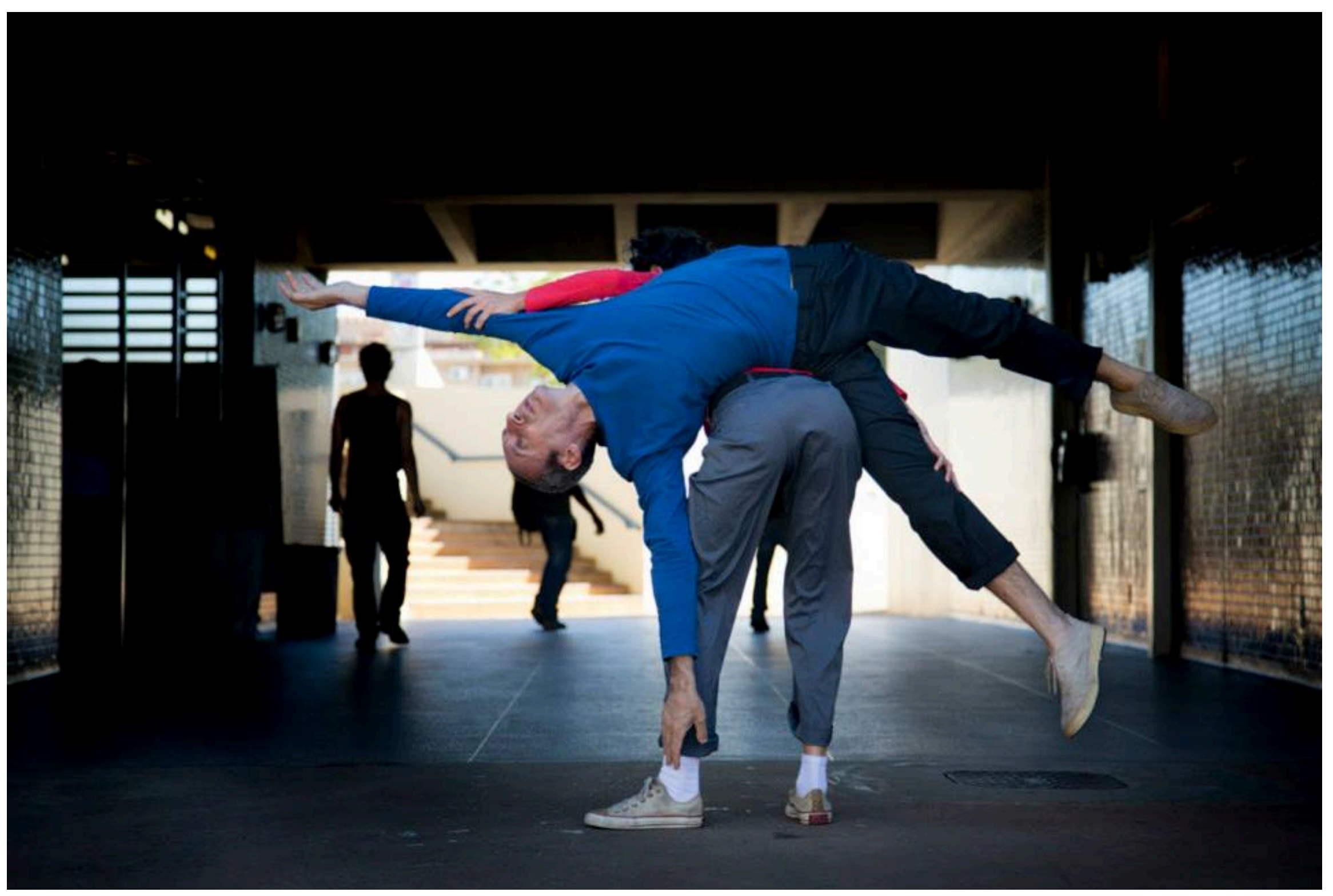




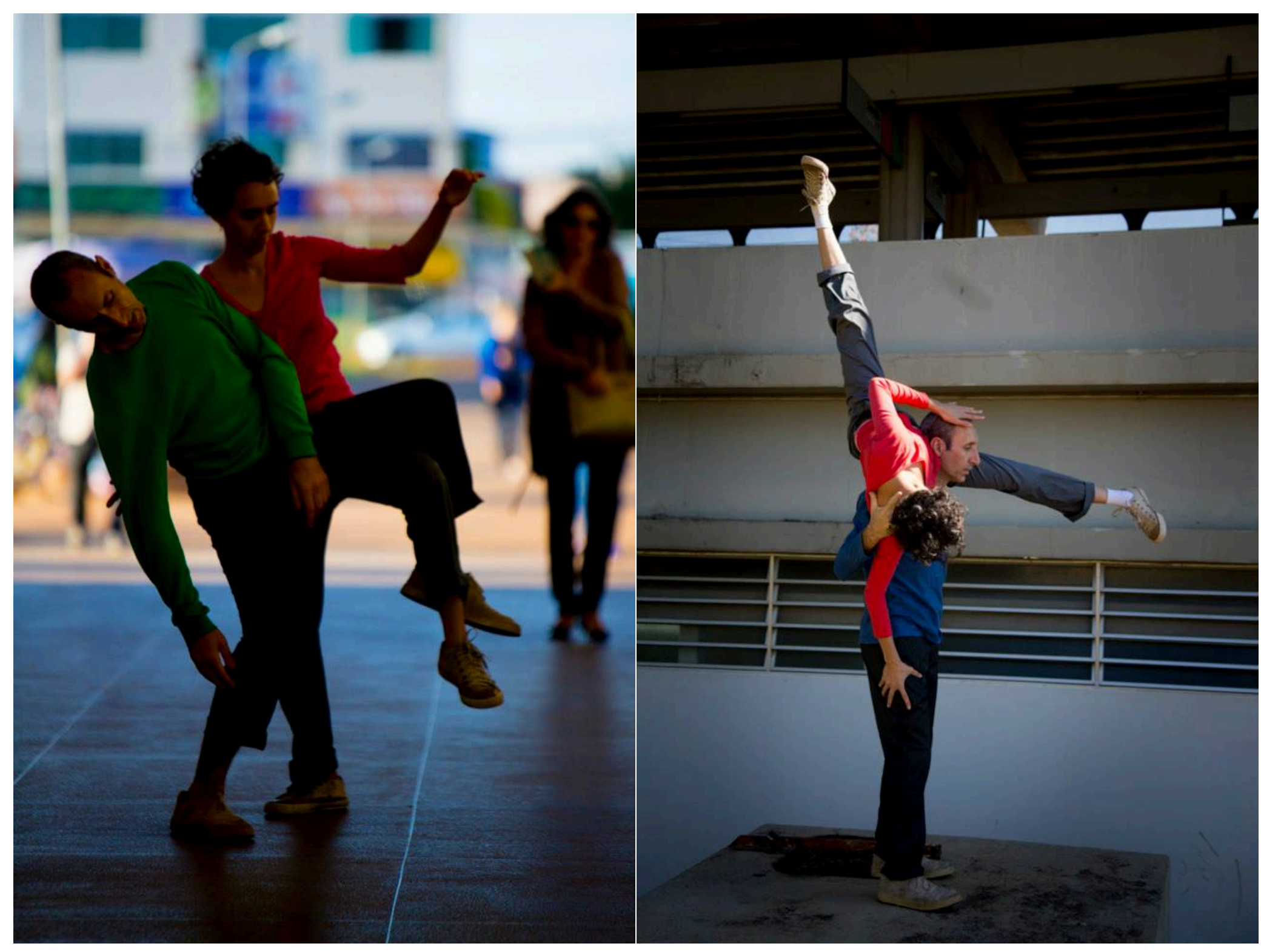




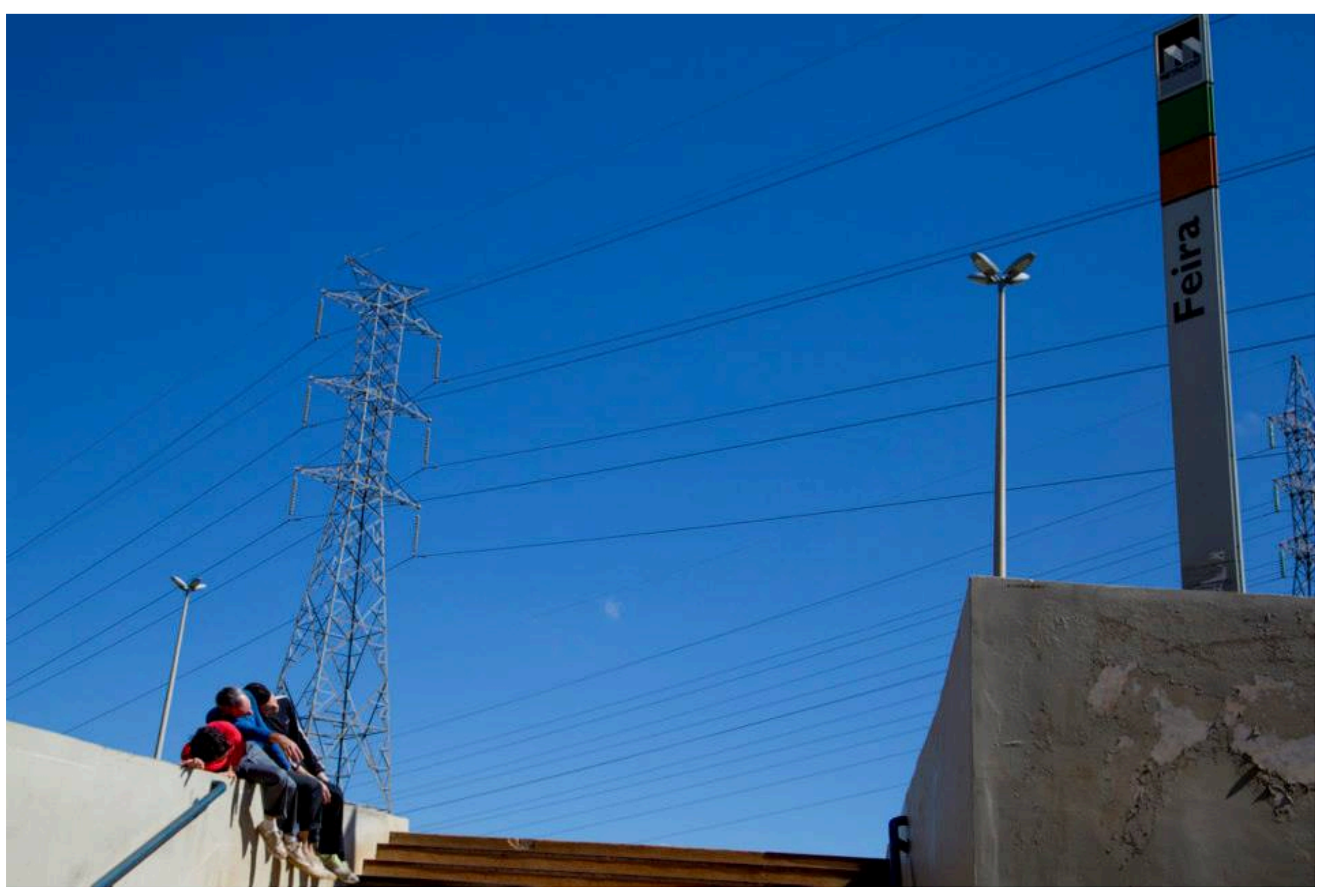




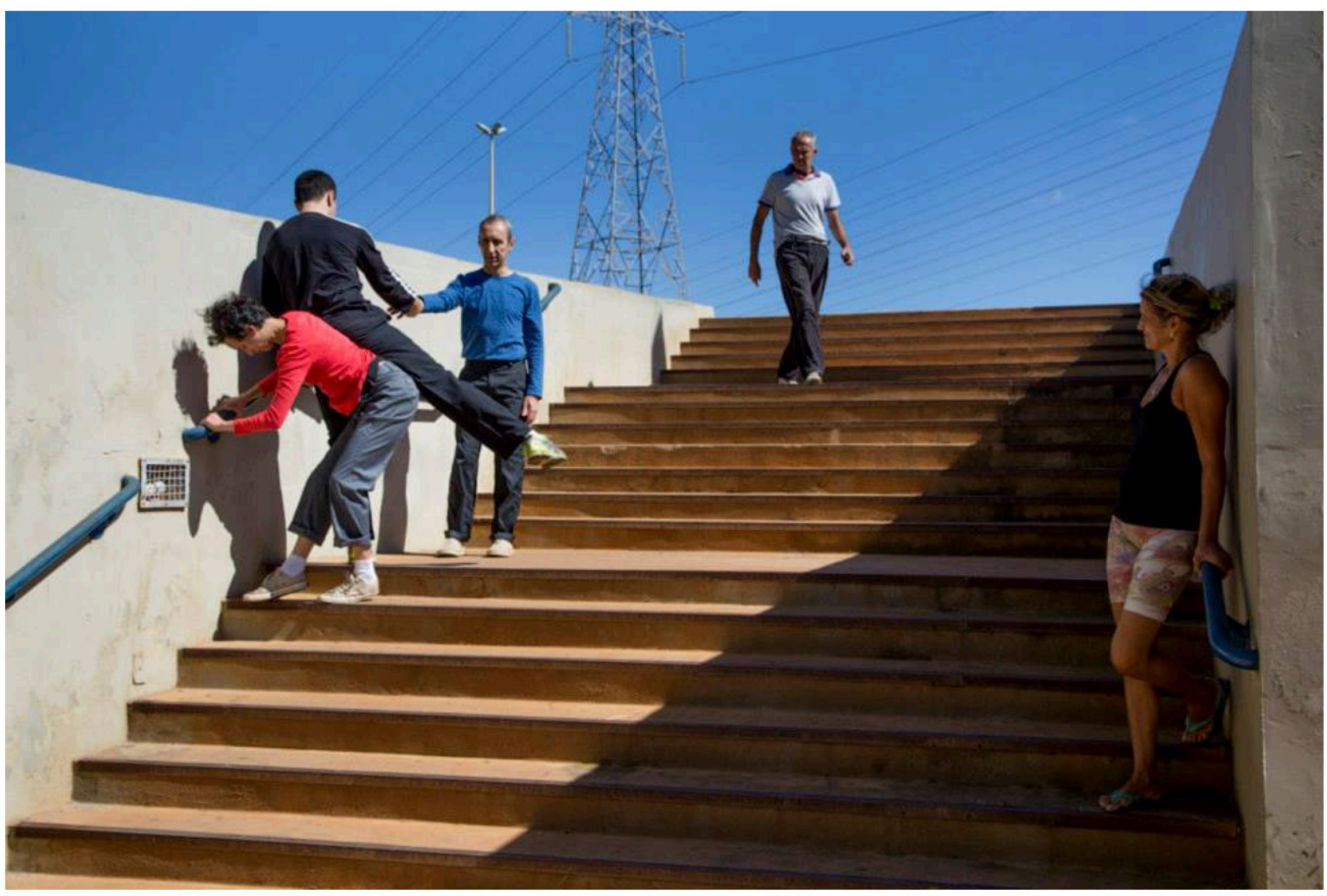




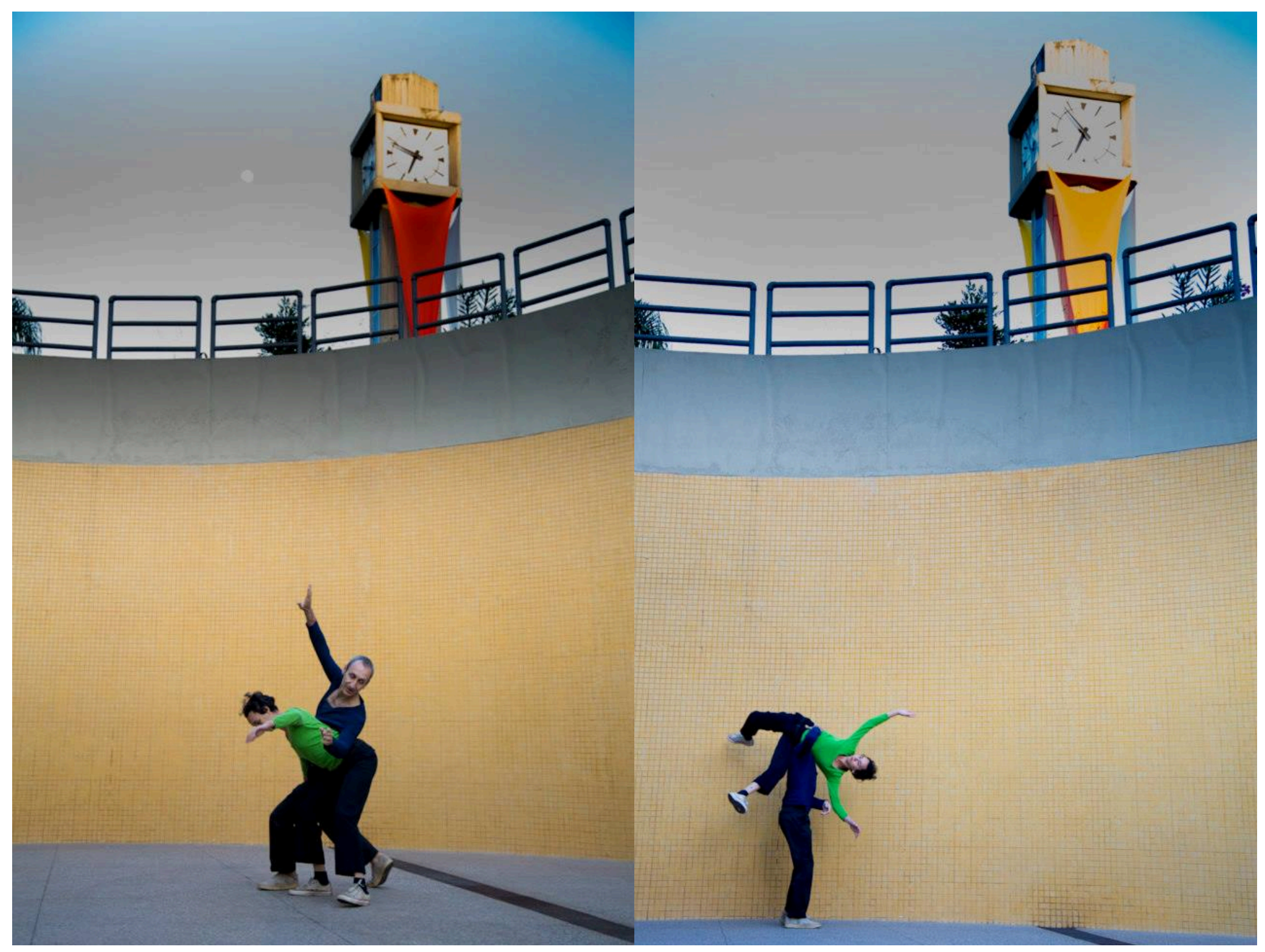




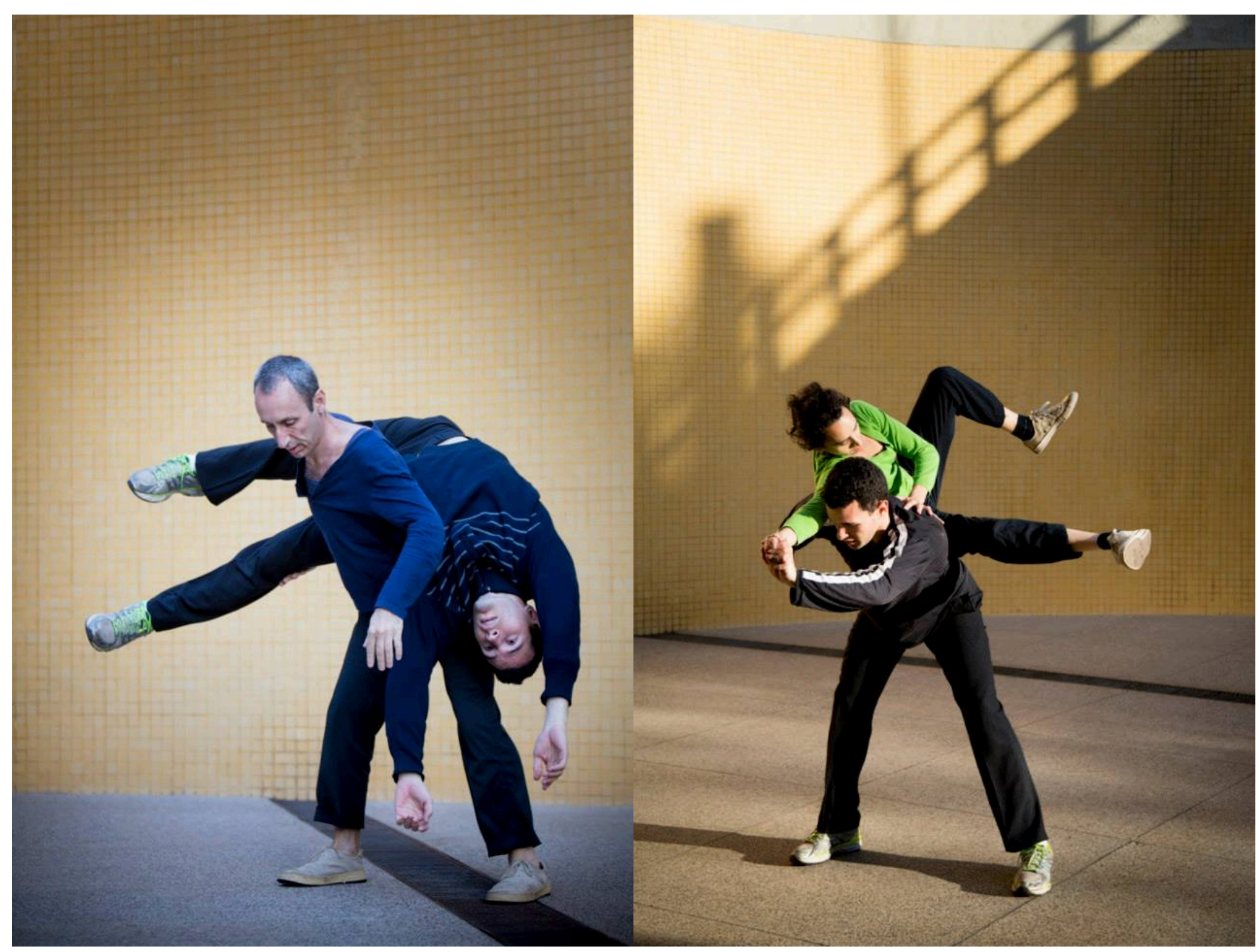




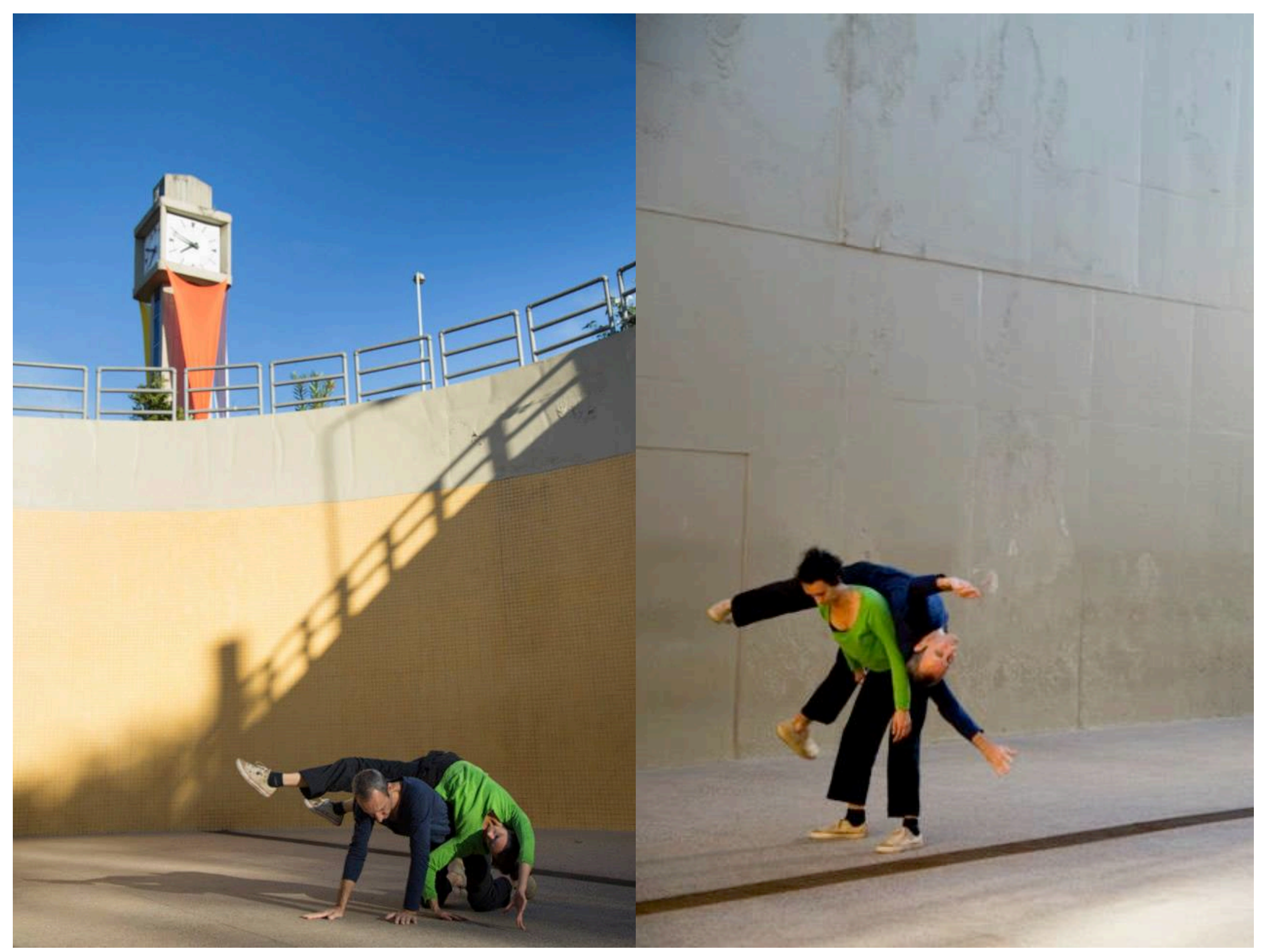




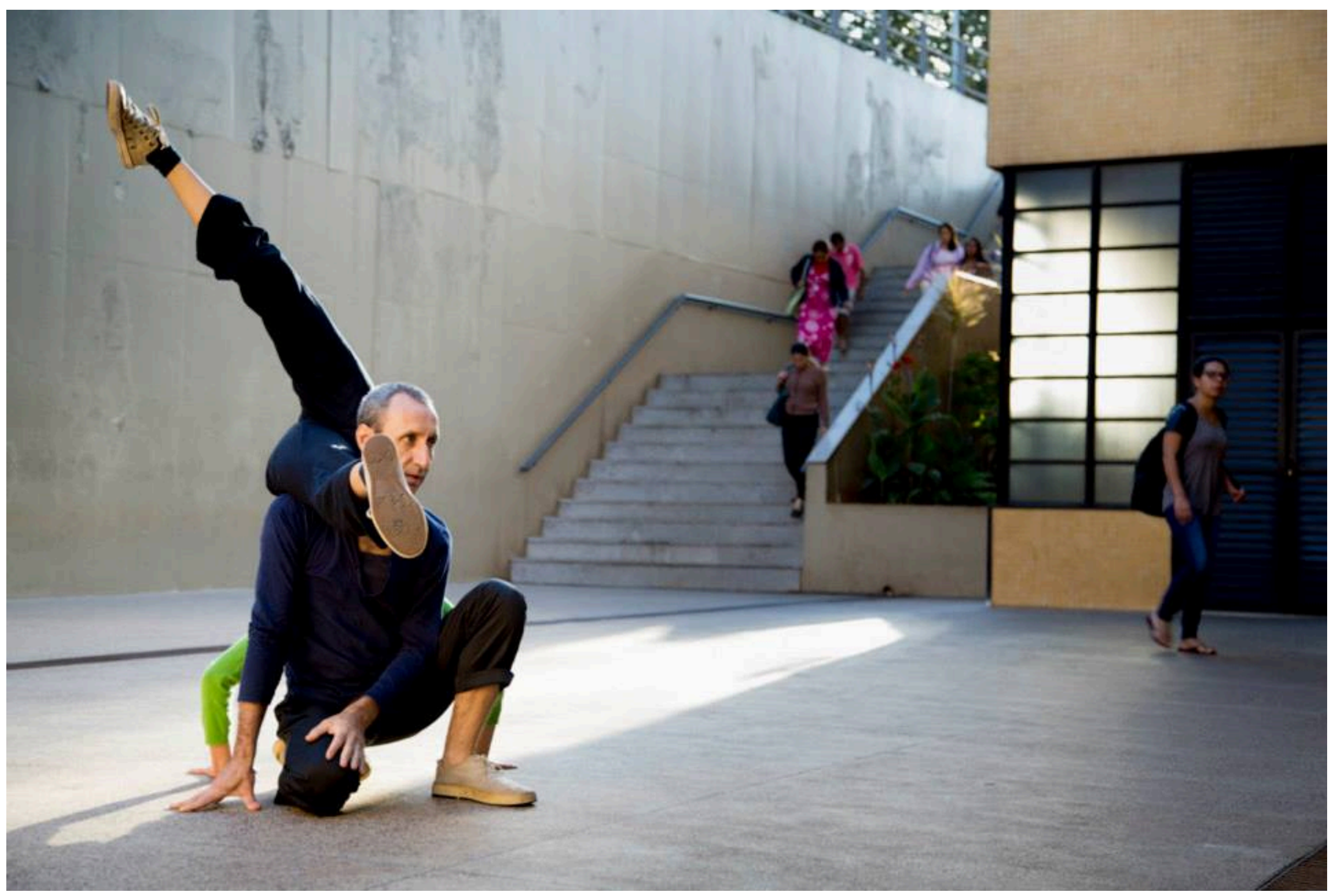




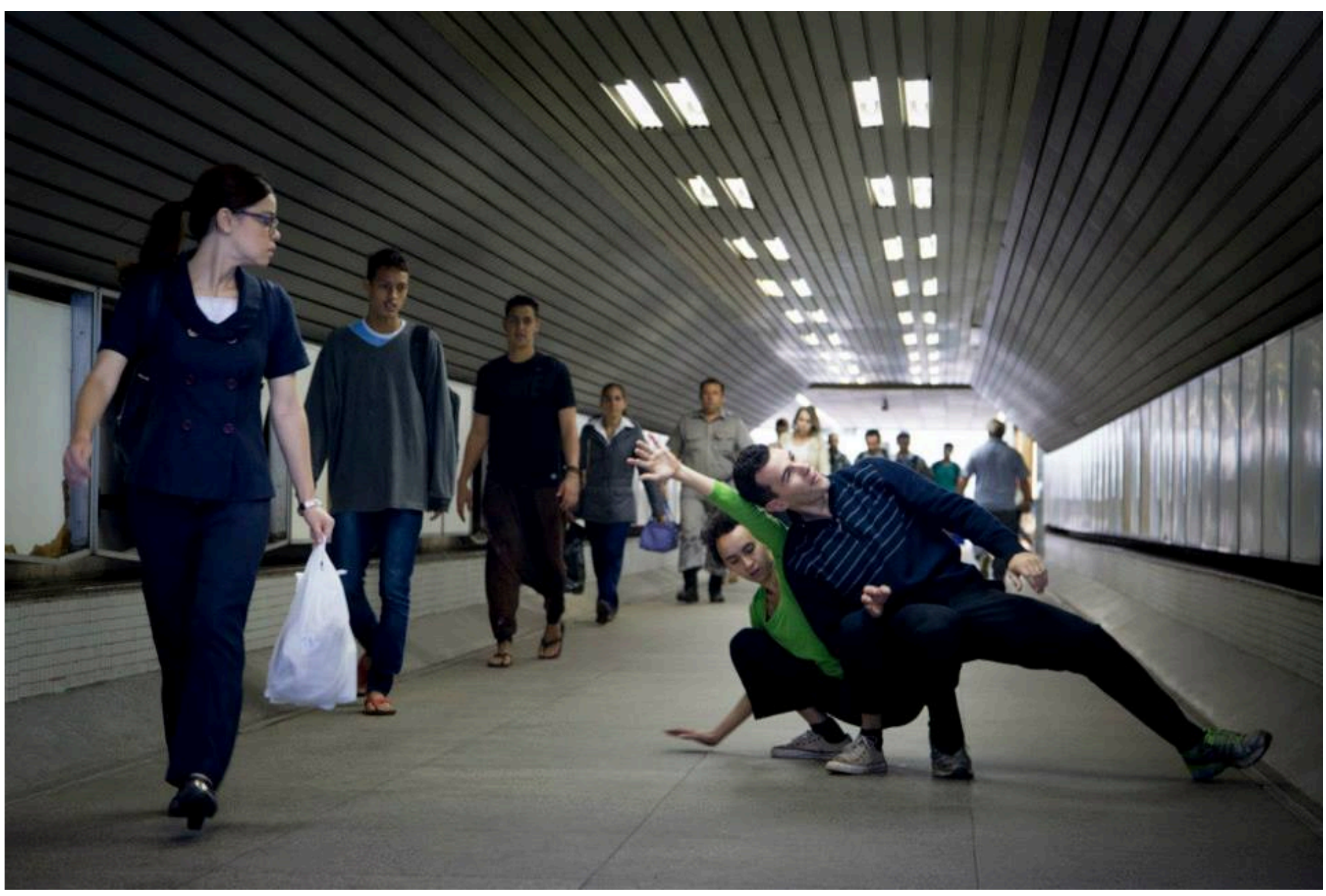




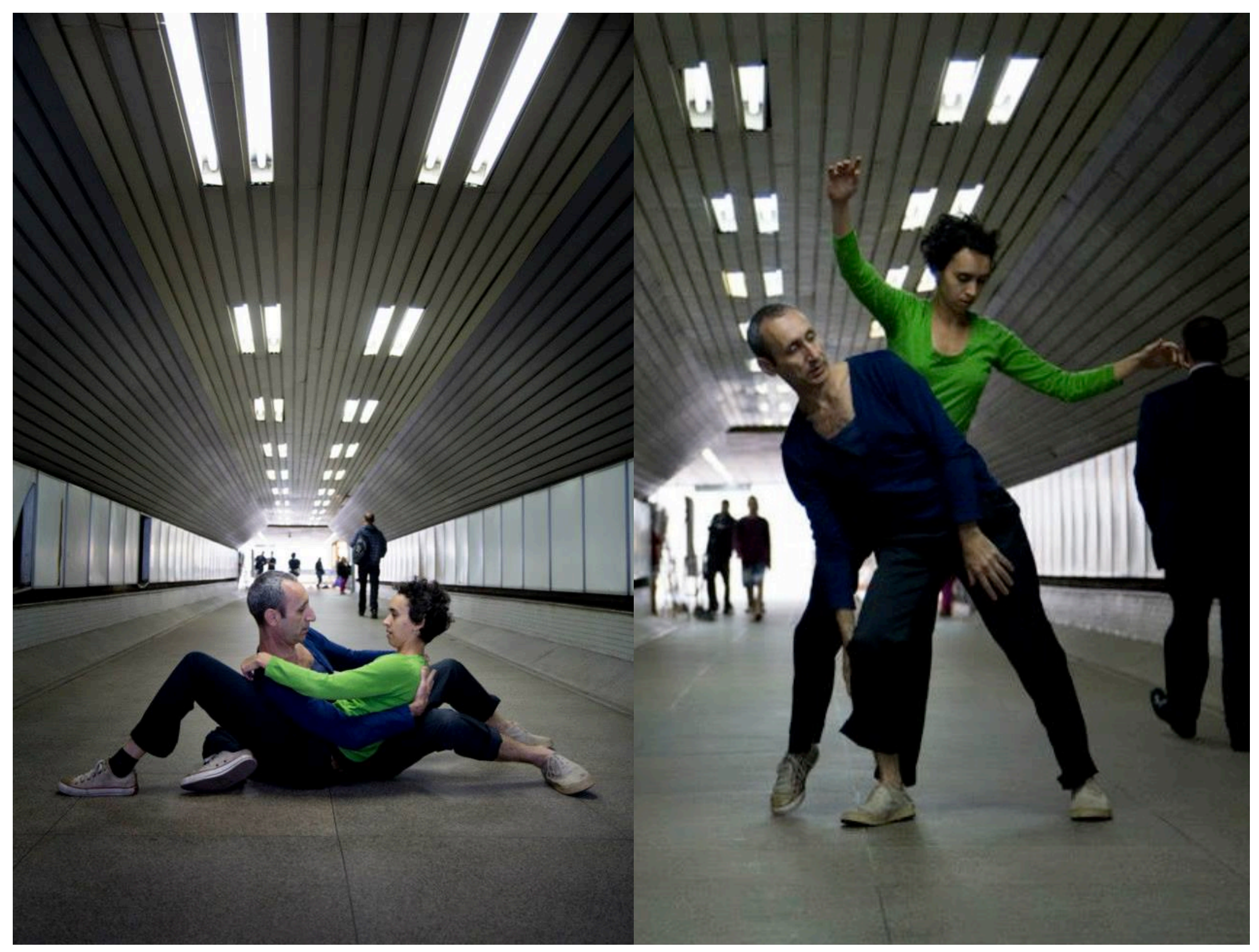




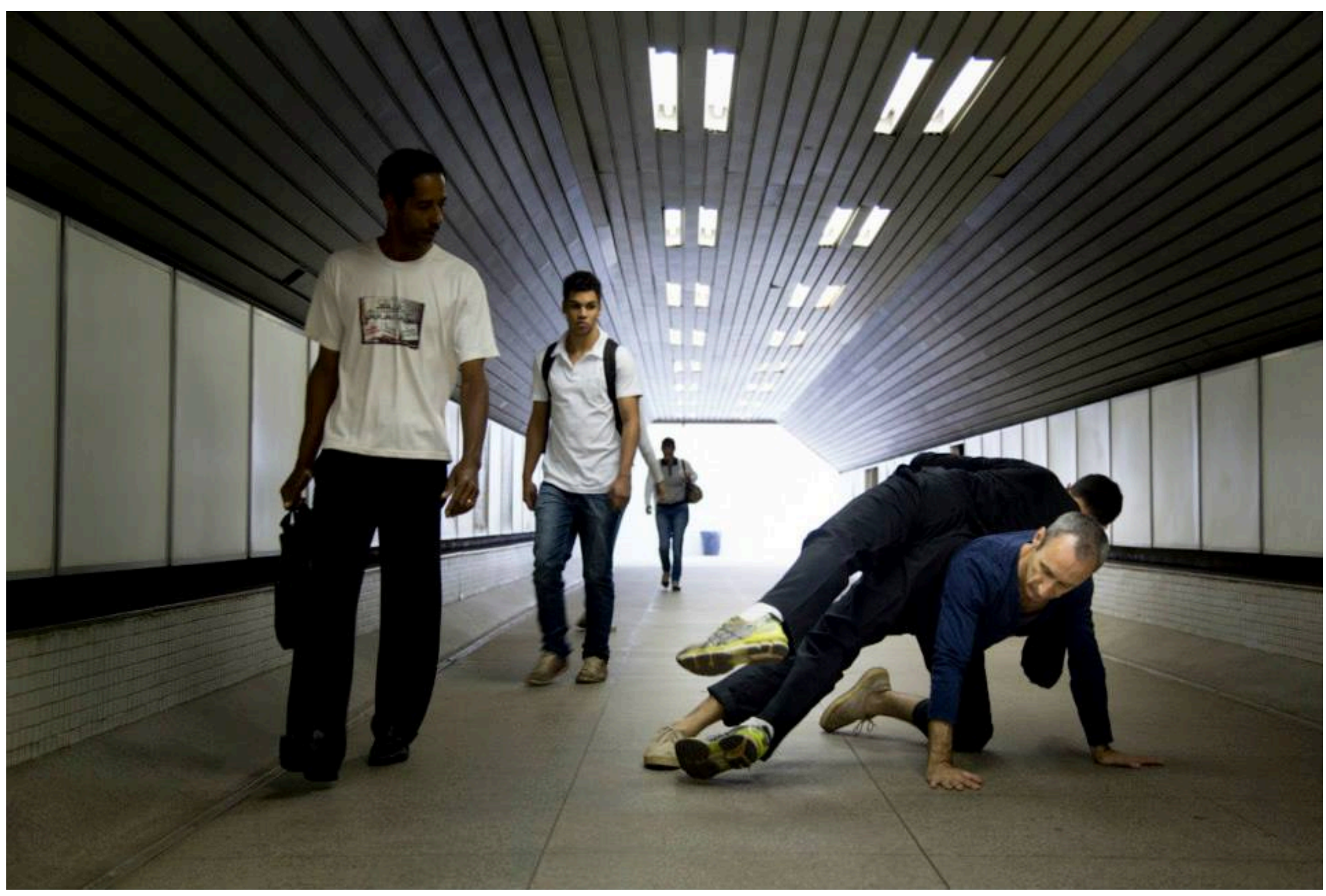




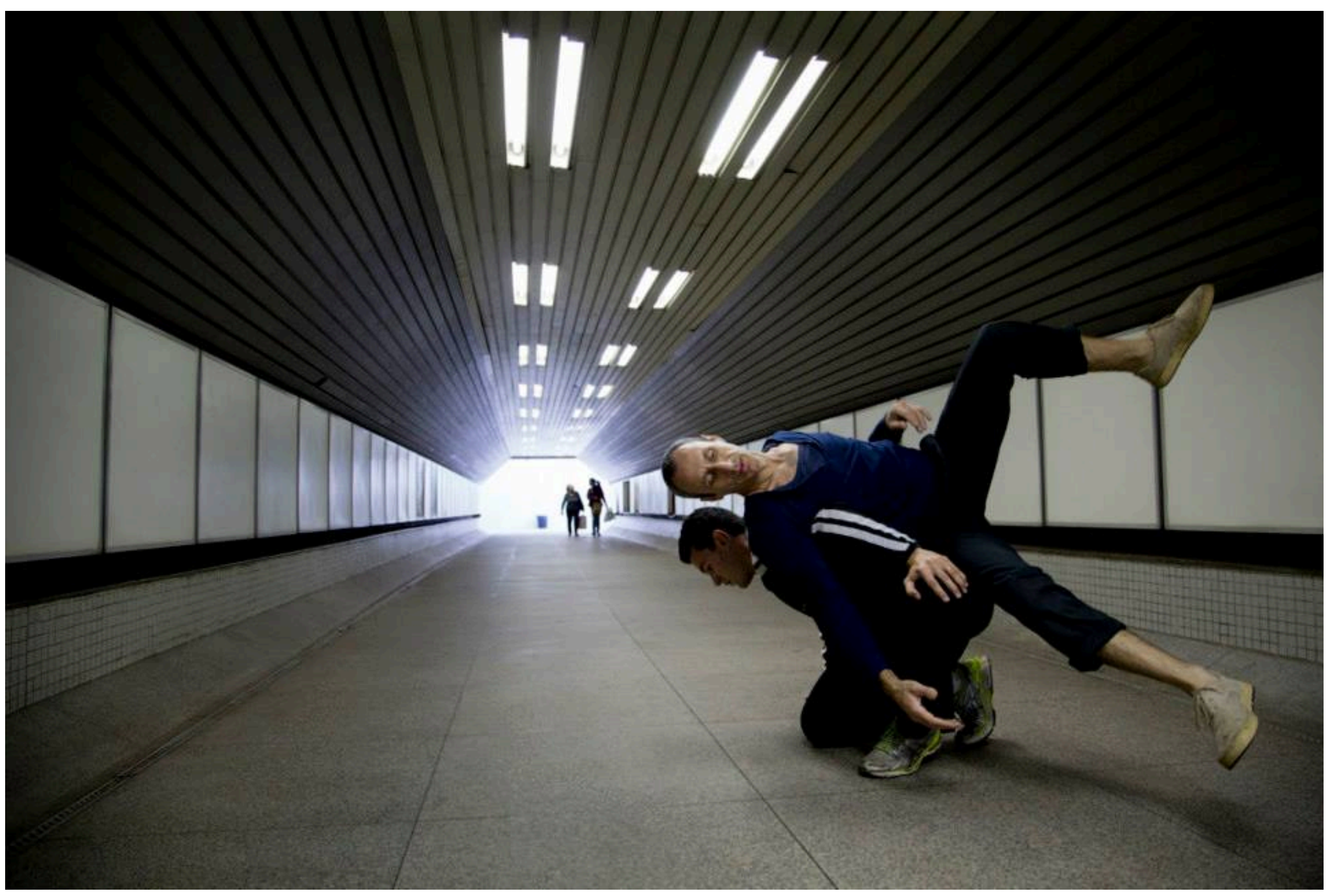




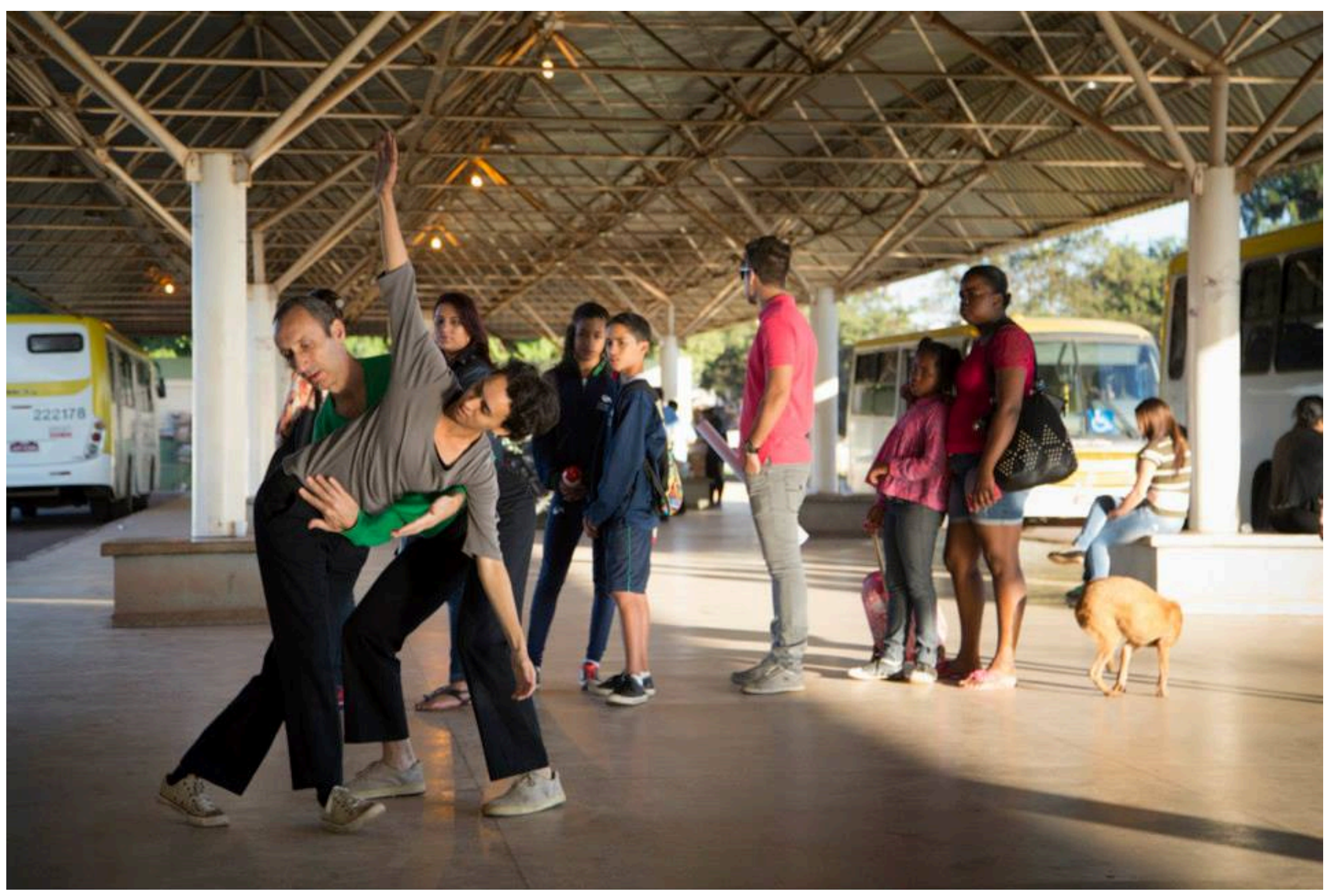




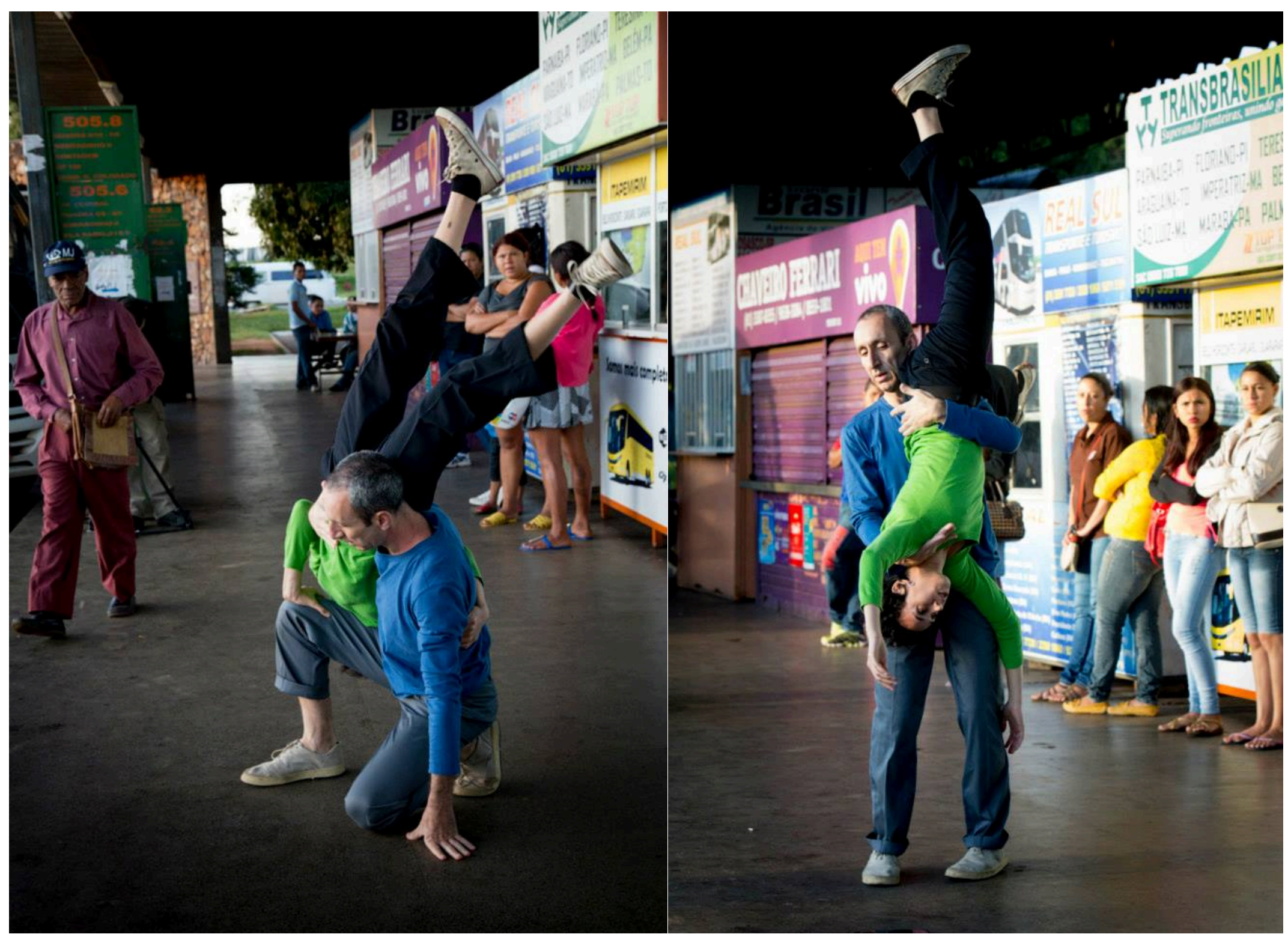



disseminar contato: estação•Rosa Schramm (rosa.schramm@gma

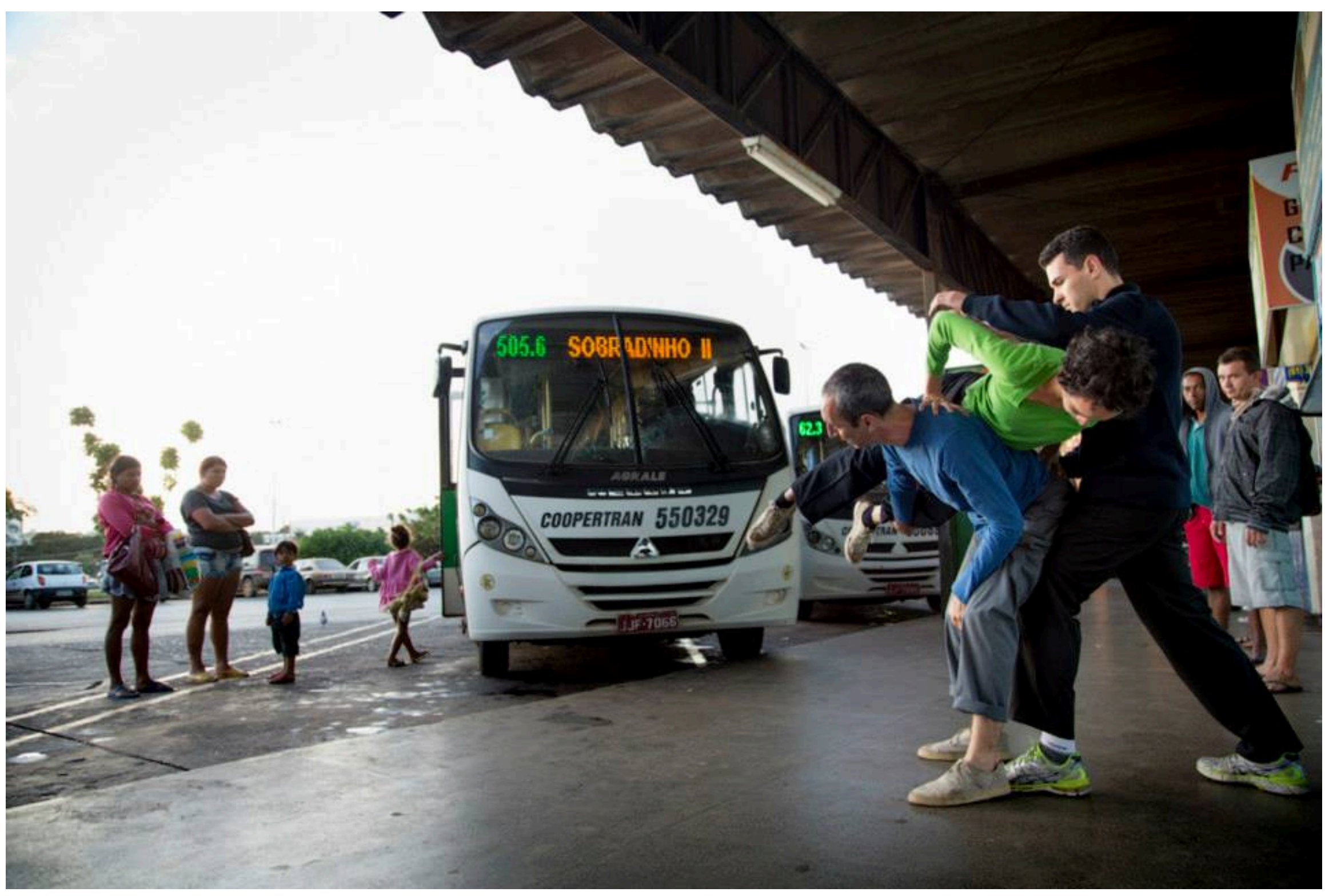


METAgraphias: letra D de Dropbox (das derivas dançantes) v.2 n.1 marçc disseminar contato: estação•Rosa Schramm (rosa.schramm@gma

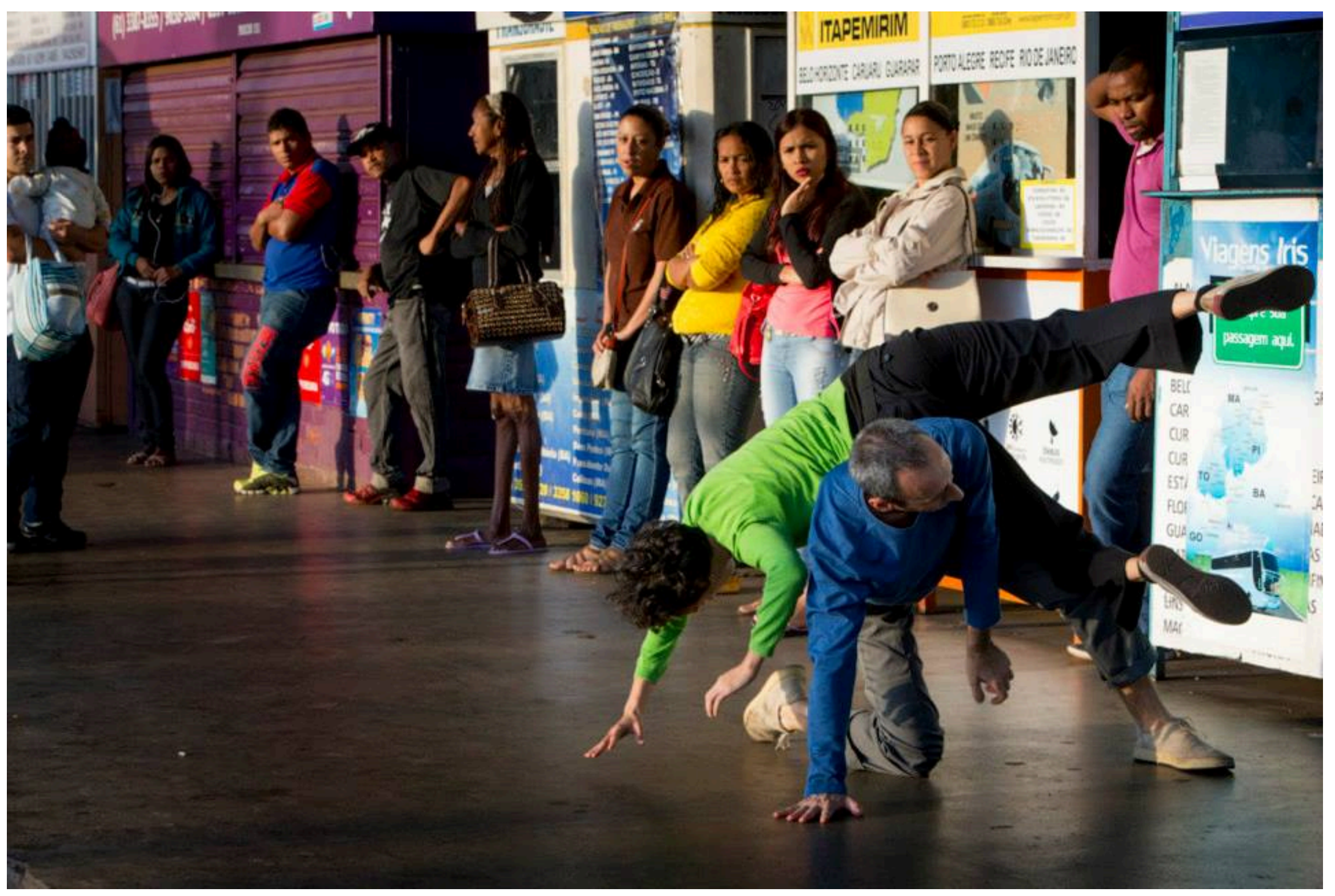


METAgraphias: letra D de Dropbox (das derivas dançantes) v.2 n.1 marçc disseminar contato: estação•Rosa Schramm (rosa.schramm@gma

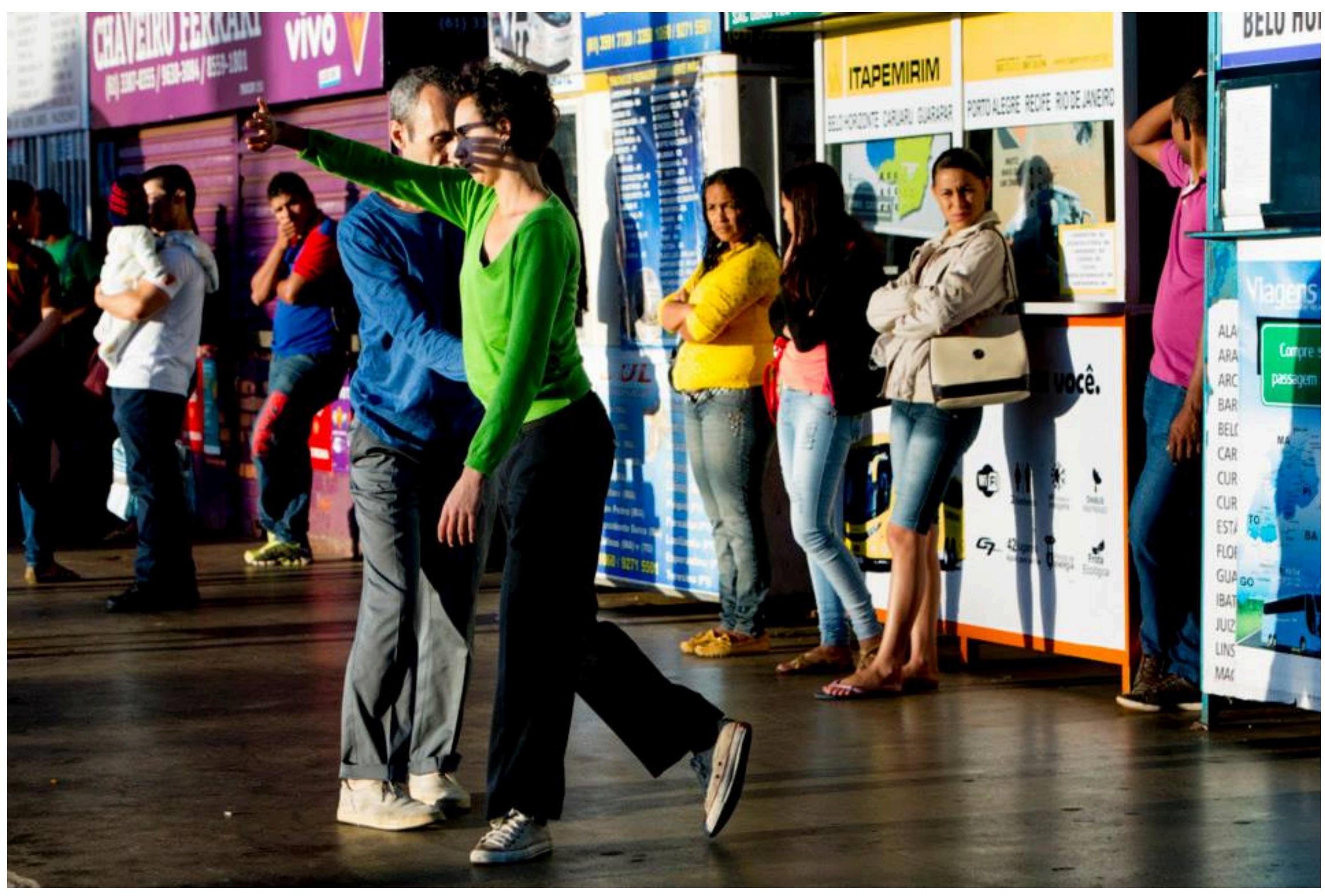


METAgraphias: letra D de Dropbox (das derivas dançantes) v.2 n.1 marçc disseminar contato: estação•Rosa Schramm (rosa.schramm@gma

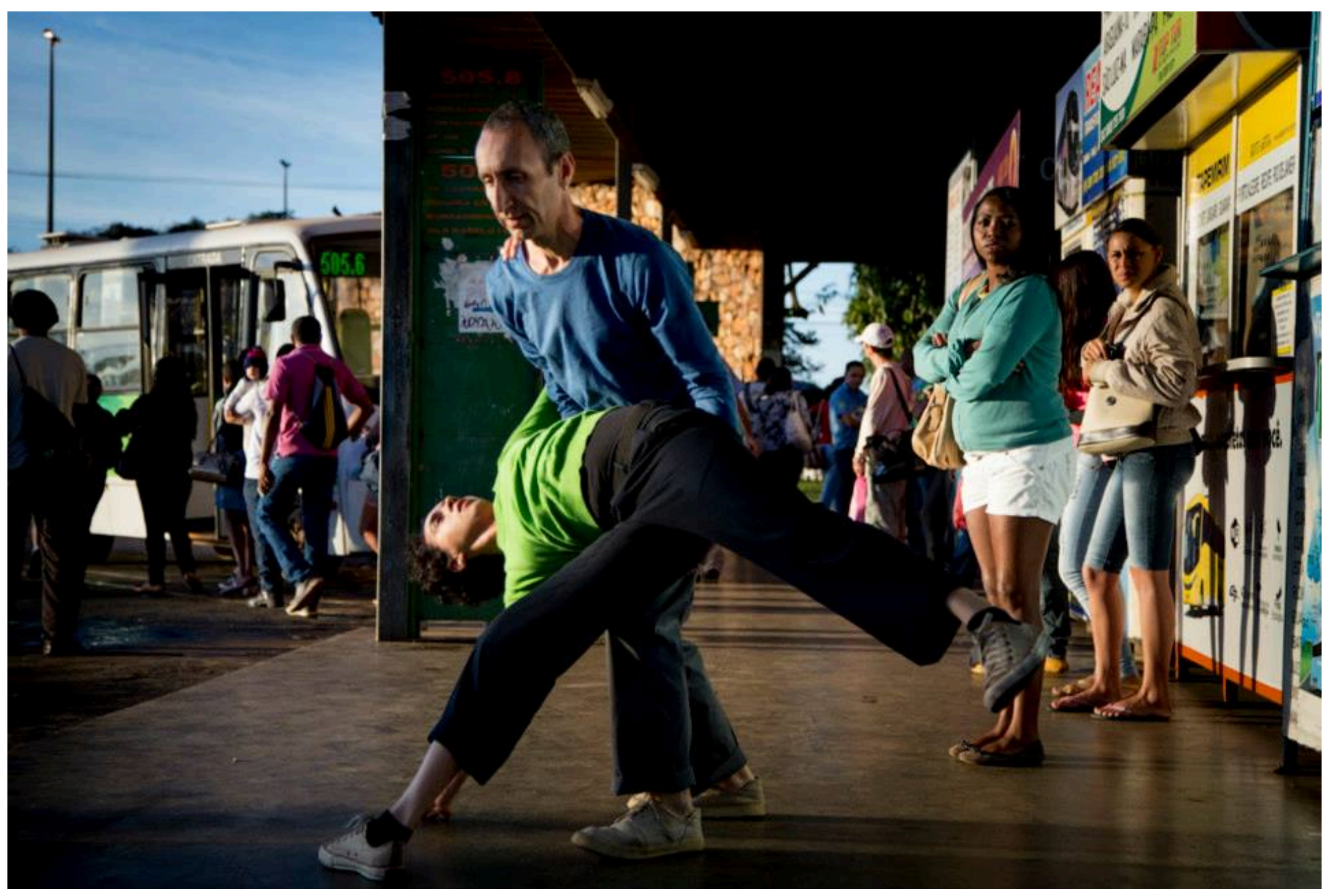


METAgraphias: letra D de Dropbox (das derivas dançantes) v.2 n.1 marçc disseminar contato: estação•Rosa Schramm (rosa.schramm@gma

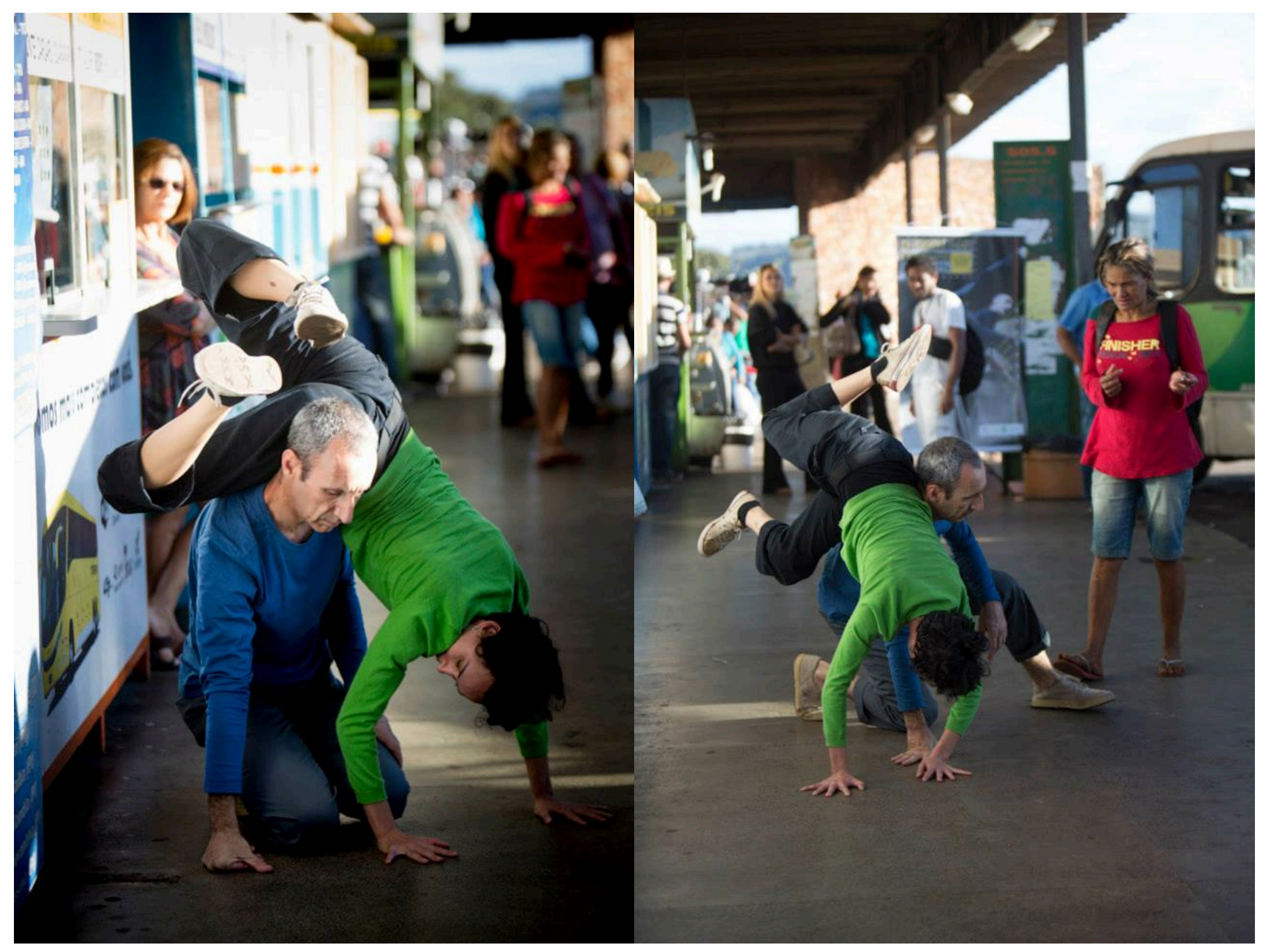




\section{disseminar contato: estação}

\section{Rosa Sch}

o movimento do sentido desposa o próprio sentido do movimento: dançar é, não significar, simb, ou indicar significações ou coisas, mas traçar o movimento graças ao qual todos estes ser nascem. No movimento dançado o sentido torna-se ação. (José Gil, 2004)

(...) e quanto aos observadores, mesmo que pela indiferença, atuam e compõe com a cena. São afetados pela presença. O pr Disseminar Contato é uma pesquisa de performance de Contato Improvisação nos grandes centros urbanos de Rosa Schramm e Ca Vacalebre. Teve inicio em 2010 com duas performances na Rodoviária do Plano Piloto com os dançarinos Camillo Vacalebre, Schramm e André Kainan como desdobramento do projeto contemplado pelo FAC, DisseminAção Com Tato de Camillo Vacalebre. 
A proposta é expor a dança do Contato Improvisação dentro de seu caráter artístico experimental e performático, ou seja, uma c minimalista isenta de artifícios cênicos. A escolha do contexto urbano, em lugares de passagem e de movimento, entre as pesso: seu cotidiano, dar-se pois percebe-se a potência criativa desse encontro tanto para os dançarinos como para o público. A arte n promove encontros, cria territórios e re-significa lugares.

Os dançarinos têm a disposição inúmeros elementos para compor a coreografia, no caso instantânea já que é sempre improvisad tempo real. Os observadores por sua vez têm acesso a manifestações artísticas no seu ambiente comum, e assim podem re-sign suas ideias quanto à arte e ao lugar que frequentam, pois somam uma outra camada cognitiva com essa experiência estética.

Em Novembro de 2010, a convite de Camillo Vacalebre, idealizador do DisseminAção Com Tato, um projeto de capacitação em Co। Improvisação, propôs uma performance na Rodoviária do Plano Piloto com Rosa Schramm e André Kainan, participantes do proje experiência foi intensa pela interação com o meio, que dispõe de forte estímulos sensoriais, como o som, o cheiro, a fumaç pessoas (frenéticas e outras nem tanto), os residentes (moradores, e pessoas que passam parte do dia ali à trabalho). Desde $\epsilon$ surgiu a necessidade de criar um espetáculo para ser apresentado também em outras rodoviárias e centros urbanos da cidade.

Neste contexto lida-se constantemente com atrito, colisões, fugas tangenciais entre todos presentes. Uma sobreposição de diferı esferas corporais como se estivem todos dançando em uma coreografia, desviando-se, encontrando-se, observando-se, cada um sua demanda e dinâmica específica, um sistema autônomo. A presença dos dançarinos criava nichos, como nódulos entre $\bar{c}$ pessoas, e ao mesmo tempo, abriam-se pontos de concentração redistribuindo os grupos pelo espaço.

\section{ISSN 2448-1246}


Considera-se a rodoviária um lugar frutífero ao proporcionar um embate direto, entre os três dançarinos e o contexto, em um es privilegiado pela grande circulação de pessoas. A maioria das pessoas que frequentam esse espaço têm pouco acesso a arte e pc confrontar (olhar, com fronte), esbarrar, tropeçar, participar desse trabalho, desviando-se de sua rotina. E para os dançarinos, hi deslocamento do espaço da dança. Lida-se com uma situação de maior atenção do que a dos contextos próprios da dança, já conversa-se com o atmosfera da rodoviária em um horário de grande fluxo de pessoas. O risco de contagiar-se atravessa os espectadores, os dançarinos e os observadores, contágio de afectos.

Steve Paxton criou a técnica de dança Contato Improvisação nos primeiros anos da década de 70. Acompanhou o fluxo vanguar ao propor não só a desvinculação com a música, com a narrativa e com a sapatilha, mas uma total desvinculação com a coreog com o espetáculo e com a verticalidade - característica dos corpos de seu professor Merce Cunningham - marcado pelo centr gravidade, a pélvis, rigorosamente sustentados pelos bailarinos. A dança inicia-se à partir de um ponto de contato que se desen' como um jogo de pergunta e resposta. Os dançarinos trocam informações como direção, intensidade, altura, peso, mantendo-s contato e em movimento constante. A composição nesses termos é instantânea, não apenas improvisada como reivindica Paxtc estrutura de contato estimula o social, por pressupor pelo menos uma dupla, além do fato de ser aberta, independente das cond físicas, o que rompe com o sistema de seleção das escolas de dança. Rompe também com os de hierarquias e de direção, como gênero, tão típica em quase todas as danças. No Contato Improvisação conduzir é também deixar-se levar, uma troca mútua. $\Lambda$ dança as mulheres também carregam, dão suporte e suspendem os homens.

\section{ISSN 2448-1246}


O Contato Improvisação fundamenta-se em um jogo que brinca com o equilíbrio dos corpos em um estado diferenciado ou termos do criador da técnica, uma consciência inconsciente. Fazer performance é viver para si com o outro. Os diferentes conc trazidos pela performance parecem adequar-se as questões artísticas da contemporaneidade, já que está relacionada a uma quali. vivência, o momentum, no movimento de ver e sentir, ver com a pele, sentir com o corpo aberto aquém da organização padrão.

A definição de arte performática abrange a participação do público, a noção de obra coletiva, de anti-arte, de exploraçã cotidianidade e re-construção corporal. Tais pressupostos contribuem para a definição contemporânea de performance, não só c campo artístico, mas também como uma postura, tanto do artista, como do público, para com a obra e o mundo circundante.

As manifestações artísticas urbanas, como na linguagem da performance e da intervenção urbana, propõem a aproximação da a vida cotidiana. O projeto entende a sutileza desse tipo de manifestação e de sua difícil aceitação/entendimento e espera pror uma experiência estética, em que a "cena" possa instigar pessoas a experimentarem-se de outras formas. Nesse sentido, o prop consiste em ampliar a mediação do sujeito com o mundo ao proporcionar outras ferramentas de lidar com o meio, consigo e cı outro. A performance nesses contextos também é uma forma de ação política, relativa ao exercício cotidiano de cidadania, pc oferece à cidade, promove arte com as pessoas. Nesse sentido, o artista é um ator (agente) político.

O projeto compreende que a dança também joga com o espectador. A simples observação dos movimentos, promove interaçãı quem assiste, pois ao acompanhar a dança, ao apreendê-la, interagimos com ela, o que quer dizer que nesse diálogo, ocorrem rea e movimentos no observador. Ou seja, na dinâmica perceptiva do movimento, o corpo reage com respostas também físicas.

\section{ISSN 2448-1246}


Acompanha-se os fluxos movimentando-se. O corpo interage com as imagens, dança ao ver.

A arte urbana explora potencialidades de fragmentos expressivos de corpos anônimos em seu cotidiano. Comumente o espaç cidade é visto pelo seu caráter utilitário, no sentido de passagem ou caminho. A subversão desses espaços confere outros sentidos não os funcionais ordinários, tornando-os sítios específicos, locais transfigurados pela corporeidade de quem experimenta esse esk Milton Santos afirma que lugar é espaço praticado.

O diálogo com o espaço público fornece potenciais estéticos aos artistas e às pessoas que circulam, que frequentam a re Modifica-se a noção de espaço e de tempo, a corporeidade. A performance nesses contextos lida com diversas informações, c estimula a improvisação, pois compõe-se com várias outras performances cotidianas.

Centrar o foco no aspecto sensorial da experiência estética (a aisthesis grega) pode criar espaço para novas experiências que podem ser percebidas quando se privilegia o processo racional. A dança, enquanto modo de manifestação artística pode amp percepção psicofísica dentro do próprio sujeito e desse sujeito em grupo, em um movimento de trocas internamente externalizadc Esse processo também é consciente, ou seja, utiliza-se da linguagem para criar mecanismos de diferenciação sensório moto cognitivas de apreensão do mundo. Assim a experiência refina-se, torna-se mais maleável, pois mais adaptável. Há um campo mair relações para a consciência interagir com a sensação e a reflexão, no conhecimento imediato de si

GIL, José. Movimento Total, São Paulo: lluminuras, '

Fotos: Rayssa

ISSN 2448-1246 